\title{
The strategy of production targets and the environmental planning in construction
}

\author{
Oleg Pobegaylov ${ }^{1}$, Olga Fil ${ }^{1}$, Pavel Tchyoubka ${ }^{1}$, and Abdul Al-Shamiri ${ }^{1, *}$ \\ ${ }^{1}$ Don State Technical University, 344010, Gagarin sq. 1, Rostov-on-Don, Russia
}

\begin{abstract}
Strategic planning is a set of targeted actions and decisions that are defined by the management of the organization to achieve the desired results, using the base of almost all management decisions and a plan that ensures the implementation of the mission of the construction organization. The article deals with the tasks of strategic planning in construction, which are designed to ensure the effective allocation of resources, adaptation to external factors, controlled coordination of financial and production aspects of activity, organizational strategic foresight. The review of the author's experience in solving the problems of planning using innovative methods and technologies was made.
\end{abstract}

\section{Introduction}

The basis of environmental planning of construction is the definition of options for the possible use of natural resources and conditions by comparing the prerequisites for the development of the economy and its limitations for each type of economic activity. In this article we will consider the principles that allow taking into account this factor.

The advancement of information technologies brings about multiple changes such as economic globalization trends, competition among businesses, shorter life cycle of product, time and quality demands, etc to the business medium. The functional targets of the traditional system of production aimed at achieving the harmony in the low price and the higher efficiency will not adapt to the current tendencies. Faster time of production, customization of products, saturation of network production, intellectual production etc make up the basis of the main subsystem of the building contractor that supplies key products to their users to be highly competitive in the market. Therefore, functional objective targeting is critical to the design of the system of building production [1].

A production system is an input system where production resources turn to products or half-made products. The system includes a production process and any related equipment, software, and personnel. The system also includes the whole process or just a part of the life circle of the product, e.g. market analysis, product design, plan of production process, assembly, transportation, marketing of the product, after-sale servicing, residual waste processing etc. Thus, a production system should be treated both as an economical, social, humanitarian medium and also as a huge complex social system $[2,3,4]$. The principal

* Corresponding author: oc41@bk.ru 
functional targets of the production system should be researching it in terms of time, quality, value, efficiency, and ecology protection.

Analyzing the interdependence between consumer needs, competitive strategy, on one hand, and the system of functional task production on the other, proves the key issue of a production system [7-10].

\section{Goal, tasks, methods of study}

Numerous researchers view clients from different angles. Like, O.A. Pobegailov [11] believes that the consumer's demand in the building market is the harmonization of the strategy of joint use of benefits and distribution of risks among the sellers and buyers. V.V. Kostyouchenko [7] argues that the clients' demand depends on the aim of investing relevant resources, mainly of time and money, to obtain a product of objective quality and quantity. We maintain that the client's satisfaction and loyalty are the two factors of measuring the consumer's demand to serve as the basis of the contractor's operation.

The competitive strategy here is regarded as the basis to realize the share of the company in the market. The majority of researchers insist that, at the income and outcome points, the supply chains may soften the impact of a marketing strategy by facilitating a better supply efficiency. Organizationally, a complete marketing strategy should include some sales forecast information as well as technological information, sales volume etc. A marketing strategy may be divided into four aspects: the order of processing information, labor information, strategic information, and information about competitors [5-8].

The literature on the subject maintains that the marketing aspect of the strategy possesses the following three aspects: informational, financial, and strategic operations [1013].

Cost, meeting the clients' needs, flexibility, innovations have always been the key evaluators for manufacturers in evaluating efficiency or operational targets. Traditionally, to evaluate the efficiency of the contractor's operations there are six indexes to be applied: actions ("work"), time, order processing, quality, customization, and customer's satisfaction $[14,15]$. Operational strategic planning keeps offers the following four types of marketing advantages in order to achieve some higher criteria: cost, quality, time, and flexibility. To impose constructional organization and planning it is essential to analyze cost, quality, flexibility, and innovations. Basing on the analysis the following four variables are shaped up: cost, level of servicing, time, and innovations in order to evaluate the functional objectives of the system [16-19].

The tighter the communication bond between the customer and the contractor, the easier they may exchange information, the better their readiness to modify their inner reinvestment information system is to lower the risk of failure of their information system and to raise the production system potential [20].

Where the contractor's strategy and production system are integrated in an interactive process, a closer contact gets achieved to result in potential customers and higher satisfaction in the prospector's operations. This also applies to environmental planning. We maintain that relations in companies may influence the information flow potential, while the accuracy in determining the customer's needs may assist the company to shape up their competitive strategy and withstand market risks [10].

A production system is a vital means of implementing a marketing strategy that needs to be timely adjusted in accordance with the challenges of the marketing strategy. A marketing strategy may produce a major positive effect on solving some system's functional problems while managing building production.

Consumer demands may produce a strong effect on the production system efficiency. Where the intensity of consumer demands gets more and more dependable on the 
production of the system's functional tasks, the production system will show some major changes by achieving capital gains from the main operations. Thus, building up the relations between consumer demand and production system in view of solving functional problems may help increase the level of dependence between the client's satisfaction and effective interaction among the customers and contractors and, further on, increase the operational efficiency of the production system. Thus, customer demands may seriously impact the production of the functional targets of the system[15].

\section{Results and discussion}

In order to study customer demands and the system of production from the angle of functional targets, the factor analysis is applied. For measuring the customer's satisfaction and demands, 15 elements of customer demands (A1 A15, Table 1) are studied. After processing the results, the factors are analyzed using the software. Calculations start at analyzing some key components: 4 factors having value 1 are studied, then their peak values get systematized with maximal bias from value 1 . After the initial factor analysis there comes interpretation of 6 other indices A4, A7, A10, A12, A14, and A15. Next, the rest 8 factors get analyzed (see their qualitative results in Table 2). An analysis of the values of the indices of a contractor under study showed 0.770 where the lowest value equals 0.5 which proves a valuable achievement, i.e. the correlation matrix possesses some common factors in the same field. [14-18].

Table 1. Problem of consumer demand.

\begin{tabular}{|l|l|}
\hline Index & \multicolumn{1}{|c|}{ Problem } \\
\hline A1 & Compliance with the amount of demand $\backslash$ expectations \\
\hline A2 & Customer expectations of the product reliability and quality of services \\
\hline A3 & $\begin{array}{l}\text { Informing customers on the quality of common value of product and } \\
\text { service }\end{array}$ \\
\hline A4 & Requirements of estimating the scope of customer's satisfaction \\
\hline A5 & Customer's estimation of product and service reliability \\
\hline A6 & Evaluation of the level of apprehension of cost in view of cost policy \\
\hline A7 & Desired charge \\
\hline A8 & Comparison between client's apprehension and expectations \\
\hline A9 & Customer's claims \\
\hline A10 & Expectations of customer's loyalty and second sales \\
\hline A11 & Charge value in a reported period \\
\hline A12 & Steps taken to increase marketability \\
\hline A13 & Working cost \\
\hline A14 & Preliminary sales and after-sale servicing \\
\hline A15 & Safety indexes \\
\hline
\end{tabular}

A study of the key component of analyzing the elements of marketing strategy shows the importance of adequate understanding of those customer's demands at level 0.821 that exceed level 0.5 .

Table 2. Analysis of the factors customer demand.

\begin{tabular}{|l|l|l|}
\hline Index & $\begin{array}{l}\text { Satisfying customer's } \\
\text { needs }\end{array}$ & Customer's loyalty \\
\hline A6 & 0.875 & \\
\hline A1 & 0.802 & \\
\hline A2 & 0.777 & \\
\hline A5 & 0.700 & \\
\hline
\end{tabular}




\begin{tabular}{|l|l|l|}
\hline A3 & 0.687 & \\
\hline A13 & & 0.813 \\
\hline A9 & & 0.736 \\
\hline A11 & & 0.701 \\
\hline A8 & & 0.684 \\
\hline Variations \% & $43.787 \%$ & $27.306 \%$ \\
\hline Total changes \% & $43.787 \%$ & $71.086 \%$ \\
\hline
\end{tabular}

Table 3. Description of marketing strategy.

\begin{tabular}{|l|l|}
\hline Factor & Problem \\
\hline B1 & Effects of the previous strategy \\
\hline B2 & Their dependence on environment \\
\hline B3 & Risk attitude \\
\hline B4 & Time strategy \\
\hline B5 & Strategy of quantitative operations \\
\hline B6 & Style of decisions \\
\hline B7 & Stability of strategic development \\
\hline B8 & Overcoming drawbacks \\
\hline B9 & Priority values at planning the development strategy \\
\hline B10 & Inter-culture conflict \\
\hline B11 & Potential competitors \\
\hline B12 & Competition and political environment \\
\hline
\end{tabular}

Table 4. Analysis of Marketing Strategy Factors.

\begin{tabular}{|l|l|l|l|}
\hline Factor & Performance & $\begin{array}{l}\text { Strategical } \\
\text { information }\end{array}$ & $\begin{array}{l}\text { Financial } \\
\text { information }\end{array}$ \\
\hline B5 & 0.852 & & \\
\hline B6 & 0.791 & & \\
\hline B 2 & 0.760 & & \\
\hline B8 & 0.691 & & \\
\hline B1 & 0.589 & & \\
\hline B11 & & 0.815 & \\
\hline B12 & & 0.750 & \\
\hline B9 & & 0.689 & 0.872 \\
\hline B3 & & 0.675 & 0.649 \\
\hline B10 & & & $18.861 \%$ \\
\hline B4 & & & \\
\hline B7 & & $22.104 \%$ & \\
\hline $\begin{array}{l}\text { Explai } \\
\text { ned } \\
\text { variati } \\
\text { ons \% }\end{array}$ & $29.186 \%$ & & \\
\hline $\begin{array}{l}\text { Total } \\
\text { chang } \\
\text { es\% }\end{array}$ & $29.186 \%$ & $51.290 \%$ & \\
\hline
\end{tabular}

The factor analysis (Tab. 3-4) shows that the functionality of the development of strategic planning directly depends on the operational evaluation of the customer's satisfaction obtained by means of monitoring. The company's position in the market of construction industry and technologies also depends on this [18]. 
Table 5. Problems of production and functional task consistency.

\begin{tabular}{|l|l|}
\hline Factor & Problem \\
\hline C1 & Technologies \\
\hline C2 & Technological innovations \\
\hline C3 & Product quality control function \\
\hline C4 & Guarantee of work quality \\
\hline C5 & Mechanism of coordinating ecological impact of production system \\
\hline C6 & Production capacity \\
\hline C7 & Production continuity \\
\hline C8 & Production system (scale and volumes) \\
\hline C9 & Systems compatibility \\
\hline C10 & Client focus \\
\hline C11 & Stability \\
\hline C12 & Marketability \\
\hline C13 & Functional flexibility \\
\hline C14 & Innovativeness \\
\hline C15 & Efficiency \\
\hline C16 & Prime cost control \\
\hline C17 & Level of requirements to the production system \\
\hline C18 & Quality guarantee \\
\hline C19 & Planning \\
\hline C20 & Level of material-and-equipment availability \\
\hline C21 & Software products \\
\hline
\end{tabular}

Studying reliability is a further way of proving the reliability of the research and the efficiency of strategic planning. We accept the factor of reliability by applying the Kronbach method, widely described in the literature. As a rule, the factor less that 0.3 shows a crisis system, from 0.5 . to 0.7 proves average stability, while 0.7 up to 0.9 indicates a high level of stability. As seen in Tab. 6, the Kronbach values applied to a variety of factors and variables show the scale of stability [13].

Table 6. Reliability by Kronbach.

\begin{tabular}{|c|c|c|c|c|c|c|c|}
\hline Cost & Factor & \multicolumn{2}{|c|}{ Kronbach values } & Varia & Kronbac & \multicolumn{2}{|l|}{ factor } \\
\hline Functional targets & Charge & 0.8177 & \multirow{6}{*}{$\begin{array}{l}0,846 \\
0\end{array}$} & \multirow{6}{*}{$\begin{array}{l}\text { Info } \\
\text { exch } \\
\text { ange }\end{array}$} & Info on & 0.854 & \multirow[t]{6}{*}{0.8239} \\
\hline & Quality & 0.8005 & & & $\begin{array}{l}\text { operatio } \\
\mathrm{n} \\
\text { completi } \\
\text { on }\end{array}$ & & \\
\hline & $\begin{array}{l}\text { Efficiency } \\
\text { quotient }\end{array}$ & 0.7058 & & & \multirow[t]{2}{*}{$\begin{array}{l}\text { Financial } \\
\text { info }\end{array}$} & \multirow[t]{2}{*}{$\begin{array}{l}0.786 \\
3\end{array}$} & \\
\hline & Services & 0.7146 & & & & & \\
\hline & Flexibility & 0.6912 & & & \multirow{2}{*}{$\begin{array}{l}\text { Strategic } \\
\text { info }\end{array}$} & \multirow{2}{*}{$\begin{array}{l}0.880 \\
1\end{array}$} & \\
\hline & $\begin{array}{l}\text { Environm } \\
\text { ent }\end{array}$ & 0.7031 & & & & & \\
\hline \multirow[t]{2}{*}{ Customer demand } & $\begin{array}{l}\text { Satisfacti } \\
\text { on }\end{array}$ & 0.8414 & \multirow[t]{2}{*}{$\begin{array}{l}0,821 \\
9\end{array}$} & & & & \\
\hline & Loyalty & 0.7834 & & & & & \\
\hline
\end{tabular}

Satisfaction about information exchange, such as operational efficiency, financial and strategic information results in a substantially positive effect that means a higher customer's satisfaction and contractor's stability in the building market. Moreover, the level of loyalty also affects the strategic efficiency of competition most positively. 


\section{Summary}

The research presented here confirms that both a customer's demand and a marketing strategy produce a vital impact on building production in the process of solving the system's functional problems. Thus, keeping the customer satisfied and raising the key competence of the managerial staff should be vital for improving the functional targets of a production system. Environmental planning taking into account new information systems in construction allows achieving development harmonious relationship between Nature and Society. Moreover, the levels of satisfaction and loyalty of the customers' demand produce an important positive effect on the operations of strategic planning and quality control of building production.

\section{References}

1. O.E. Gaybarian, G.I. Myasishchev, Engineering journal of don 4(47), 193 (2017)

2. E. Shirina, O. Gaybarian, G. Myasischev, S.E. Petrenko, N.S. Serpokrylov, V.Y. Borisova, Inženernyj vestnik Dona 2 (2013)

3. A.S. Beresnev, A.Y. Bolshakov, G.N. Gusev, V.V. Korkodinov, B.N. Pimenov, Int. Journal for Computational Civil and Structural Engineering 4, 34-34 (2008)

4. P. Bernstein, Against the Gods, Taming Risk (Business Olympus, Moscow, 2006)

5. A.F. Wall, R.P. Keeling, Liberal Education 4(93), 22-31 (2007)

6. T.S. Kolmykova, Investment analysis (INFRA-M, Moscow, 2009)

7. L.K. Petrenko, Proceedings of the Rostov State University of Civil Engineering, Construction and architecture 16 (2012)

8. M.V. Berlins, B.A. Yagupov, Examples of the base for calculating and foundations (Stroyizdat, 1986)

9. G.V. Simagin, Effective foundations of buildings in the lungs heaving soils (Petrozavodsk, 2002)

10. O.V. Kliuchnikova, Procedia Engineering 150, 2168 - 2172 (2016)

11. V.V. Kostyuchenko, Organization, planning and management in construction: textbooks (RSSU, Rostov - Don, 2012)

12. V.N. Migunov, Experimental and theoretical modeling of reinforced structures under corrosion (Penza, PGUAS, 2014)

13. L.M. Puhonto, Durability of reinforced concrete structures engineering structures (silos, hoppers, tanks, water towers, retaining walls) (ASV, Moscow, 2004)

14. E.B. Nikolenko, Organizational-economic mechanism of investment support of $R \& D$, Dis. (Ufa, 2012)

15. A. Lentz, T.H. Johnsen, M.H. Faber, Proceedings of First International Conference on Bridge Maintenance, Safety and Management, 365-366 (2002)

16. S.N. Stepanov, PhD Thesis. (NSABU, Nizhny Novgorod, 2005)

17. V.V. Kostyuchenko, Special course of organization of construction (RSSU, RostovDon, 2013)

18. E. Miller, Investments Translated from English (Olympus-Business, Moscow, 2013)

19. A.V. Shilov, S.E. Manzhilevskaya, K.V. Gubarev, Inženernyj vestnik Dona 3 (2015) ivdon.ru/ru/magazine/archive/n3y2015/3155

20. V.A. Pogorelov, Scientific Review 7, 741-744 (2014) 